\title{
TERMELÉSI FOLYAMATOK ANYAGELLÁTÁSI RENDSZERÉNEK SZIMULÁCIÓS MODELLEZÉSE
}

\section{SIMULATION MODELING OF MATERIAL SUPPLY SYSTEMS OF PRODUCTION PROCESSES}

\author{
Tóth Norbert ${ }^{1}$, Garamvölgyi Ernö ${ }^{2}$ \\ ${ }^{I}$ Bay Zoltán Nonprofit Kft., H-3519, Magyarország, Miskolc, Iglói út 2; \\ notbrt.toth@bayzoltan.hu \\ ${ }^{2}$ Bay Zoltán Nonprofit Kft., H-3519, Magyarország, Miskolc, Iglói út 2; \\ erno.garamvolgyi@bayzoltan.hu
}

\begin{abstract}
This paper introduces simulation models for analyzing of a material supply system of production and assembly processes at a manufacturing company, including the functional elements and the main parameters of the model. The developed model can be used not only for testing of different operational strategies without the modification of the real system, but also for analyzing the operation in a costeffective and more organized way.
\end{abstract}

Keywords: production logistics, material flow, modeling, simulation.

\section{Összefoglalás}

A cikk egy termelő vállalat gyártási és szerelési folyamataihoz kapcsolódó anyagellátási rendszer elemzéséhez szükséges szimulációs modell elkészítését mutatja be, magába foglalva a modell funkcionális elemeit és legfontosabb paramétereit. A kidolgozott modell lehetővé teszi különböző müködtetési stratégiák kipróbálását, a rendszer költséghatékonyabb és szervezettebb müködtetésének elemzését a müködő valós rendszer módosítása nélkül.

Kulcsszavak: termelési logisztika, anyagáramlás, modellezés, szimuláció.

\section{Bevezetés}

A termelö vállalatok legfontosabb célja a vevői igények minél magasabb színvonalon történő kielégítése, amely magába foglalja a rendelések határidőre való elkészítését és megfelelő minőség biztosítását. A vállalat verseny-képességének fokozásában jelentős szerepet játszik a termelési folyamat minél hatékonyabb müködtetése. A termelés hatékonyságát nagymértékben befolyá-solják a folyamatban jelentkező logisztikai tevékenységek, amelyek a gyártáshoz és szereléshez szükséges alapanyagok, alkatrészek és félkésztermékek megfelelő időpontban, mennyiségben és minőségben való rendelkezésre állását biztosítják. A hatékonyság növelését, a termelési folyamatban fellelhető veszteségek csökkentésével lehet elérni [1], amely elsősorban a produktum létrejöttéhez szükséges nonproduktív tevékenységekre irányul. Ilyen tevékenységek a logisztikai müveletek [2], amelyek számossága és ideje nem ha- 
nyagolható el a tiszta gyártási (állapotváltoztató) müveletek idejéhez viszonyítva. A termelési folyamat veszteségeinek csökkentését segíti elő a vele szoros kapcsolatban álló logisztikai folyamatok hatékonyságának növelése is. A logisztikai müveleteket integráltan magukban foglaló termelési folyamatok komplex, sok paraméterrel, számos állapotjelzővel jellemezhető gyártási rendszerek vizsgálatához, optimalizálásához elengedhetetlen a termelési folyamatok számítógépes modellezése.

\subsection{A vizsgált rendszer bemutatá- sa}

A cikkben egy termelési logisztikával kapcsolatos problémát mutatunk be, amelyben a termelő egységek anyagellátása került modellezésre. A termelőrendszer számos gyártó-, és szerelőcellából épül fel (1. ábra). A cellák együttesen több egymást követő gyártási fokozatot valósítanak meg. A cellákban különböző számú munkahelyek találhatók, ahol az egyirányú és egy munkadarabos (one piece-flow concept [3]) anyagáramlás a jellemző. A fóegységbe a munkahelyi tárolókból származó alkatrészek, részegységek és saját gyártású félkésztermékek épülnek be. Az elkészült szerelvényt készterméknek vagy további beépülés esetén félkészterméknek tekintjük. A késztermékek a készáru raktárba, míg a félkésztermékek valamelyik közbenső tárolóba kerülnek további felhasználás céljából. Mivel a vizsgálat elsősorban a targoncás járatok kihasználtságára irányul a cellában zajló szerelési folyamat nem került részletes modellezésre, csupán a beépülő alkatrészek számának mennyisége vált fontossá számunkra, amelyből az alapanyagfogyás dinamikáját meg lehetett állapítani. Egy cella feldolgozhat más cellák által készített félkésztermékeket is, amelyeket az egyes gyártási fokozatok között elhelyezett tárolókból kézi anyagmozgató eszközökkel szolgálunk ki, ezért ennek modellezését elhanyagoltuk.

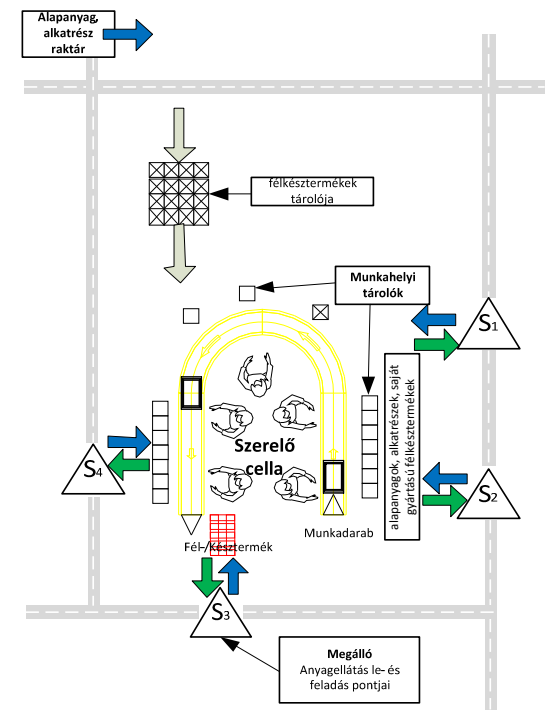

1. ábra. Szerelő cella anyagellátása

Az anyagellátást targoncás milkrun járatok valósítják meg, amelyek egy üzemen belüli központi alapanyagraktárból kiindulva látják el a cellák anyag-szükségletét. A cellák anyagigénye kétféle módon kerül meghatározásra. Egyrészt KANBAN kártyák alapján kerülnek feltöltésre a munkahelyi tárolók, másrészt a cella előre - egy bizonyos időintervallumra vonatkoztatva - a saját termelési programja alapján határozza meg az alapanyagigényét (JIS ellátási stratégia szerint), így kisebb egységekben és rövidebb idő lefedésére elegendő alapanyag kerülhet kiszállításra. Ez a megoldás előnyös, hiszen a tárolóterület mérete csökkenthető, viszont csak jól szervezett, ütemes menetrendben közlekedő cellákhoz rendelt milkrun járatokkal lehet megvalósítani. A cellákhoz dedikált megállóhelyek kerültek kialakításra, ahol az alapanyag targoncáról való leadása illetve az üres göngyölegek mellett a kanban kártyák felvétele is megtörténik. Az üres göngyölegek göngyölegtárolóba kerülnek. Ezt követően a kanban kártyáknak megfelelő mennyiségü alapanyag komissiózására kerül sor, amelyet az alapanyag-ellátó jármü a következő 
ütemezett indulási ciklusában szállít ki a megfelelő helyre. A szerelő cellák nagy száma miatt számos targoncás járat üzemeltetésére volt szükség. A logisztikai és anyagmozgatási költségek csökkentése érdekében elsődleges szemponttá vált ezen járatok kapacitás-kihasználtságának növelése, járatok összevonásának vizsgálata szem előtt tartva a termelés folyamatosságának és zavartalan müködtetésének biztosítását.

\section{A modell funkcionális elemei}

A vizsgált rendszer szimulációs modelljének kifejlesztését alapvetően három, egymással szoros kapcsolatban álló tevékenység jellemezte. Ezek a következök (2. ábra):

- A rendszer felépítése alapelemekböl, a modell objektumainak és a köztük lévő anyagáramlási kapcsolatok definiálása.

- A rendszer viselkedésének kialakítása: a modell metódusai foglalják magukba azokat az eljárásokat és függvényeket, amelyeket egy-egy tevékenység vagy folyamat leképzésére alkalmaztunk.

- Megfelelő adatstruktúra kialakítása: a nagy mennyiségben rendelkezésre álló alapadatok felhasználására hatékony megoldást nyújtott a relációs adatbázis alkalmazása, a megfelelően strukturált adattáblákból való lekérdezések révén.

A felsorolt jellemzők figyelembe vették az alkalmazott PlantSimulation modellező szoftver sajátosságait is. A modellezett rendszer bemenő paramétereinek egy részeként megkülönböztettünk úgynevezett statikus paramétereket, amelyek értékét nem lehetett megváltoztatni, így ezen paraméterek nem képezték a vizsgálatok tárgyát:

- a cellákra vonatkozó ütemidők (takttime [4.]), átlagos átállítási idők;

- a milkrun járatok esetében az átlagos szállítási sebesség, az átlagos le- és felrakodási idők az egyes megállókban;

- vontatott kocsik átlagos maximális kapacitása;
- müszakrendek.

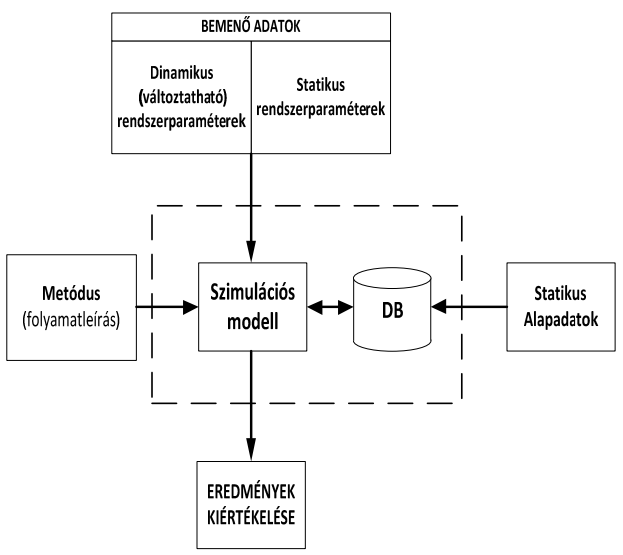

2. ábra. Szimulációs modellhez kapcsolódó funkcionális elemek

A bemenő paraméterek másik csoportját a változtatható (dinamikus) paraméterek adják. Értékeik változtatása hatással van a vizsgált rendszerre:

- a szükséges milkrun járatok száma;

- a vontatott kocsik megengedett maximális száma;

- a járatok ütemideje;

- a járatok útvonalának meghatározása, járatokhoz megállók rendelése,

- homogén/inhomogén járatok engedélyezése az anyagellátás során (ez a döntési változó arra vonatkozik, hogy egy milkrun járat csak a KANBAN kártyás anyagellátást láthassa el vagy egyúttal a JIS-es típusú anyagellátást is).

$\mathrm{Az}$ elkészült szimulációs modell egy részletét mutatja be a 3 . ábra. A modellezés eszközeként egy diszkrét-eseményvezérelt gyártási folyamatok szimulációjára alkalmas szoftvert alkalmaztunk, amelyben a szerelöcellák, a milkrunjáratok, a müvelet- és gyártási fokozatok közti tárolók mellett az anyagmozgatási folyamatok is leképzésre kerültek. 


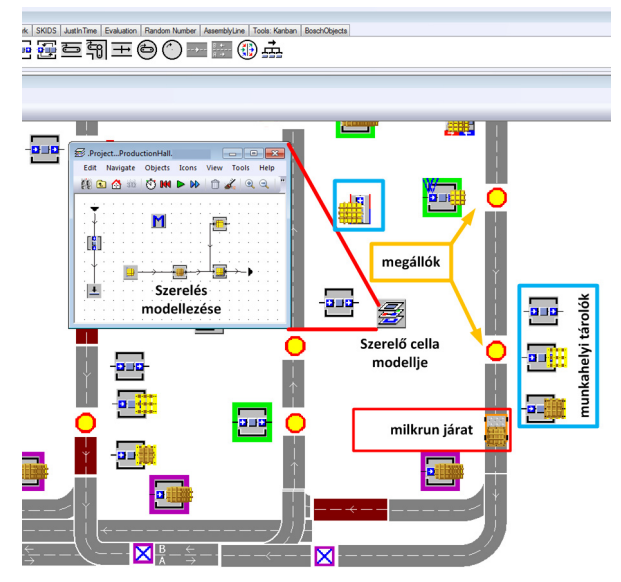

3. ábra. A vizsgált rendszer PlantSimulation környezetben elkészitett szimulációs modellje

\section{Következtetések}

A szimulációs vizsgálatok során elsősorban a targoncás járatok kapacitáskihasználtságának vizsgálatára tértünk ki. Alapesetben a vontatható kocsik maximális száma 4 volt, és inhomogén járatokat engedtünk meg minden olyan esetben, ahol ez lehetséges volt. Kezdetben 9 targoncás járatszervezést vizsgáltunk. A futás eredményeképpen a targoncák kihasználtsága 35\% és $72 \%$ közé esett. 2 járat esetén $33 \%$ és $55 \%$-ban volt szükség a 4 kocsira, a jellemző az 1-2 vontatmány volt. A második esetben homogén járatokat engedtünk meg, ezzel csökkentve bizonyos járatok megállóhelyeinek számát, amely a járatok kihasználtságának csökkenését eredményezte, hiszen egy-egy kör rövidebb idő alatt bejárhatóvá vált. A vontatható kocsik maximális számát 6-ra emeltük. Egy járat esetén 23\%ban volt csupán szükség a 6 kocsira, többnyire 2-3 pótkocsi elegendőnek bizonyult.
A harmadik esetben inhomogén járatokat vettünk alapul, maximum 6 lehetséges vontatmánnyal. A kezdeti 9 járatot - egy járat megszüntetése és másikkal való összevonása révén - egyel csökkentettük. Az adott járat - amellyel az összevonás történt - kihasználtsága 5\%-al növekedett. A vontatott kocsik számának százalékos megoszlásában nem mutatkozott szignifikáns különbség az előző esethez képest. Az egyes vizsgált esetekben az alacsony kihasználtságokért a rövid szállítási útvonalak a felelősek, ami további járatösszevonások vizsgálatának alapjául szolgálhat. A modell alkalmassá vált a gyártási fokozatok közötti készletek vizsgálatára is. Kimutattuk, hogy a készletek csökkentéséhez az előszerelő cellák termelésütemezését felül kell vizsgálni, és olyan termelésütemezési modellek, módszerek kialakítása válik szükségessé, amely integráltan képes kezelni az anyagellátáshoz kapcsolódó logisztikai erőforrásokat is.

\section{Szakirodalmi hivatkozások}

[1] Husi Géza: A lean alapú termelés kialakitásának lépései, Debreceni müszaki Közlemények VI. évf. 2. szám Debrecen, 2007, 59, HU ISSN 1587 - 9801.

[2] Cselényi J., Illés B.: Logisztikai rendszerek I., Miskolci Egyetemi Kiadó, Miskolc, 2004. 6.

[3] Deechongkit, Songwut, and Rawinkhan Srinon: The Framework of Synchronizing Material Supply Approaches with Facility Layout Design for Mixed Model Assembly Line, Proceedings of the International MultiConference of Engineers and Computer Scientists. Vol. 2., 2013, 870, ISBN 978-98819252-6-8.

[4] Marton, Michal, et al: One piece flow another view on production flow in the next continuous process improvement, Slovak University of Technology Bratislava, 2011, 30-35. 